\title{
IS TRADE AGAINST OR IN FAVOR OF WOMEN? EMPIRICAL EVIDENCE FROM MANUFACTURING SECTOR IN TURKEY
}

\author{
TİCARET, KADINLARA KARŞI MI, ONLARIN LEHINE Mİ ÇALIŞIR? \\ TÜRKIYYE IMMLAT SEKTÖRÜNDEN AMPİRIK KANITLAR
}

\author{
Şerife GENÇ İLER $\dot{I}^{*}$ \\ Mehmet Fatih ULU ${ }^{* *}$ iD
}

\begin{abstract}
This paper studies the effect of trade openness on relative wage earnings of female workers in Turkey's manufacturing sector. We compute the export intensity of a sector by dividing the export value to production value as our measure of trade openness. Using Structure of Earnings Survey data for 2010 and 2014, we estimate the impact of export intensity on the gender wage gap. Our results indicate that a onepercentage point increase in the export intensity of a sector leads to a 0.17 percent higher gender wage gap. We further investigate the trade-gender wage gap link by grouping the sectors into four quartiles according to their export intensities. Our estimations for each quartile reinforce our finding of a negative impact of trade on the male-female wage inequality. Lastly, we analyze how the wage gap between men and women change according to skill levels. In line with the previous findings in the literature, we estimate a higher wage discrimination against high-skill women.
\end{abstract}

Keywords: Wage Inequality, Female wages, Gender wage gap, Trade, Export Intensity

JEL Classification: J16, J24, J31, J71

Öz

Bu çalışma, ticaretin Türkiye imalat sektöründeki kadın işçilerin göreli ücret kazançları üzerindeki etkisini incelemektedir. Çalışmada kullanılan ticarete açıklık değeri, sektörlerin ihracat değerini üretim değerine bölerek hesapladığımız sektör ihracat yoğunluğudur. 2010 ve 2014 için Kazanç Yapısı Araştırması verilerini kullanarak, ihracat yoğunluğunun cinsiyetler arası ücret farkı üzerindeki etkisini ölçmekteyiz. Sonuçlarımız, bir sektörün ihracat yoğunluğundaki bir yüzde puanlık artışın kadın ve erkekler arasındaki ücret farkını yüzde 0,17 oranında arttırdığına işaret etmektedir. Sektörleri ihracat yoğunluklarına göre dörtte birlik gruplara ayırarak yaptığımız analiz de benzer sonuçlar vermektedir. Erkekler ve kadınlar arasındaki ücret farkının eğitim seviyelerine göre nasıl değiştiğine baktığımızda ise, literatürdeki önceki bulgulara paralel olarak, yüksek eğitimli kadınların daha fazla ücret ayrımcılığına maruz kaldığı sonucuna ulaşmaktayız.

1 Asst. Prof., Ibn Haldun University, Department of Economics, Istanbul, E-Mail: serife.genc@ihu.edu.tr, ORCID ID: 0000-0002-5214-2583

2 Asst. Prof., Koc University, Department of Finance, Istanbul. E-Mail: mulu@ku.edu.tr, ORCID ID: 0000-0001-8691-7503 
Anahtar Kelimeler: Ücret Eşitsizliği, Kadın Ücretleri, Kadın-Erkek Ücret Farkı, Ticaret, İhracat Yoğunluğu JEL Sınıflandırması: J16, J24, J31, J71

\section{Introduction}

It is a well-known fact that female workers are in a disadvantaged position against their male peers in terms of both earnings and employment status. The gap between median wages of men and women in OECD countries is $13.5 \%$ and there is recently very little progress towards closing the gender pay gap. ${ }^{1}$ The discrimination against women in labor markets is a globally important issue in terms of its social, economic impacts, and policy implications. Empirical evidence shows that promoting the income of females in a household improves health and educational outcomes of children and hence is very important in terms of long-run growth prospects of especially the developing countries. ${ }^{2},{ }^{3}$ In that respect, it is essential to understand the factors that affect the relative well-being of women in labor markets.

Segregation of women in low-paid jobs and positions ${ }^{4}, 5$, institutional factors related to work-family relations such as parental leave and child-care policies, the design of pay-bargaining institutions, and unionization in labor markets are mentioned in the literature as possible factors that affect the relative wage earnings of women. The hierarchical structure of labor markets has also been discussed as a factor generating a higher gender wage gap. Differing promotion and appointment procedures in labor markets where the appointment of a worker may depend on his/her negotiation skills, and bargaining power has the potential to affect the relative earnings of women in the labor market. ${ }^{6,7,8}$

Besides the above-mentioned factors, the degree of trade exposure of a country is also studied as an important force in shaping the wage inequality between male and female workers. Our objective in this paper is to explore the link between the gender wage gap and trade in Turkey, which is a developing country with a particularly low female labor force participation rate ${ }^{*}$ and an overall

1 World Economic Forum (2019). Global Gender Report 2020, p.17.

2 Thomas, D. (1990). Intra-Household Resource Allocation: An Inferential Approach, Journal of Human Resources, 25(4): 635-664.

3 Duflo, E. (2003). Grandmothers And Granddaughters: Old Age Pension and Intra-Household Allocation in South Africa, World Bank Economic Review, 17(1): 1-25.

4 Bayard, K., Hellerstein, J., Neumark, D., Troske, K. (2003). New Evidence on Sex Segregation and Sex Differences in Wages from Matched Employee-Employer Data, Journal of Labor Economics, 21(4): 887-922.

5 Amuedo-Dorantes, C., de la Rica, S. (2005). The Impact of Gender Segregation on Male-Female Wage Differentials: Evidence from Matched Employer-Employee Data for Spain, IZA Discussion Papers 1742.

6 Arulampalam,W., Booth, A. Bryan, M. (2007). Is There a Glass Ceiling over Europe?, Exploring the Gender Pay Gap across the Wage Distribution, ILR Review, 60(2): 163-186.

7 Albrecht, J., Björklund, A., Vroman, S. (2003). Is There a Glass Ceiling in Sweden?, Journal of Labor Economics, 21(1): 145-177.

8 Antonczyk, D., Fitzenberger, B., Sommerfeld, K. (2010). Rising Wage Inequality: The Decline of Collective Bargaining, and the Gender Wage Gap, Labour Economics, 17: 835-847.

* As of September 2020, the female labor force participation rate is 33\% and it is the lowest among OECD countries followed by Mexico where around $45 \%$ of the women participate in the labor markets. Source: International Labour Organization, ILOSTAT Database. (Accessed on: 20.09.2020). 
gender wage gap of $15.6 \%{ }^{9}$. We combine individual and firm-level data provided in 2010 and 2014 waves of the Structure of Earnings Survey with industry-level information on export and production values of the manufacturing sector. We construct an export intensity measure for each subsector under manufacturing and estimate the impact of export intensity on the wage gap between males and females. We also explore this link on an additional dimension by analyzing the trade and gender gap relation for different skill categories. In Turkey, 2018 figures show that gender wage is highest among workers with elementary level or less education and it is the lowest among college and above education group ${ }^{10}$. The variation in the overall gender wage among different education groups makes the skill dimension worth exploring.

The results of our analysis show that more trade exposure, which we measure as the export intensity, generates a higher gender wage gap in Turkey's manufacturing sector. According to our estimations, a 1 percentage point rise in export intensity stimulates a 0.17 percent higher male wages relative to female wages. Moreover, our analysis of the trade-gender wage gap relation for two different skill groups shows that in sectors with the highest export intensity, the gender wage gap is higher among skilled workers compared to the unskilled. This result is in line with other findings in the literature that trade liberalization hurts skilled women more than unskilled ones. ${ }^{11},{ }^{12}$

Our results provide support to the non-neoclassical view that the gender wage gap rises with increased trade relations in Turkey. Previous work that find a similar result, attribute this outcome to the degree of market competition of exporting firms. The same reasoning may explain the results we found for Turkey, as well. The increased profits due to trade may be increasing the discriminatory power of firms in concentrated industries hence generating a higher gender wage gap in the country. ${ }^{13,14}$

The rest of the paper is organized as follows. In section 2, we elaborate on the theoretical discussions about the link between trade and gender wage gap. In section 3, we present a brief review of the literature. In section 4, we explain the data and methodology. Section 5 discusses the results and section 6 concludes the paper.

\section{Trade and Gender Wage Gap}

On the theoretical ground, there are conflicting arguments regarding the relationship between trade and the gender pay gap. Neoclassical theories suggest that trade liberalization closes the pay gap between men and women. Hecksher-Ohlin and Stolper-Samuelson theorems together demonstrate that with the increased competition due to trade liberalization, each country will produce the goods

$9 \quad$ ILO and TurkStat (2020). Measuring the Gender Wage Gap: Turkey Case, p.10.

10 ILO and TurkStat, 2020, 12.

11 Yahmed, S. B. (2012). Gender Wage Gaps Across Skills and Trade Openness, AMSE Working Papers, 1232, 1-33.

12 Juhn, C., Ujhelyi, G., Villegas-Sanchez, C. (2014). Men, Women, and Machines: How Trade Impacts Gender Inequality, Journal of Development Economics, 106: 179-193.

13 Berik, G., Rodgers, Y., R., Zveglich, J. E. (2004). International Trade and Wage Discrimination: Evidence From East Asia, Review of Development Economics, 8(2): 237-254.

14 Yahmed, S. B. (2017). Gender Wage Discrimination and Trade Openness, Prejudiced Employers in an Open Industry, Zew Discussion Papers, 17-047: 1-53. 
for which it has more abundant production factors. Hence, the relative price of the abundant factor will rise in these countries. For developing countries, the relatively abundant factor is unskilled labor whereas developed countries have more of skilled labor. Since women on average have lower levels of schooling, trade is expected to create a more equitable wage distribution between men and women in developing countries. ${ }^{15}$

The non-neoclassical approach, on the other hand, argues that more intense trade engagement may increase the gender gap. According to this approach, if trade increases competition in sectors that are competing through cost reduction and female workers are employed more in these sectors, the bargaining power of female workers will be reduced hence gender gap may rise. ${ }^{16}$

Another line of argument supporting the view that trade diminishes the gender wage gap can be found in Becker's theory of discrimination. Some employers have a "taste for discrimination", which may raise their cost. In non-competitive markets where firms are able to make excess profits, employers can afford to pay for the discrimination they exert. However, when markets are competitive, firms do not have the opportunity to make extra payments for their discriminatory behavior, otherwise they will make negative profits. Hence, increased trade exposure reduces discrimination and the gender wage gap by increasing competition and driving down excess profits. ${ }^{17}$ Becker's theory of discrimination holds in competitive markets. However, there is the "market-size" effect of trade on a firm's discriminatory power. If the market structure is concentrated, and firms operating in these concentrated sectors that already discriminate engage in trade, this will provide them the chance to earn extra profits hence they may discriminate more and the gender wage gap may rise. ${ }^{18}$

Another theory that discusses the link between relative wage earning of women and trade highlights the effect of complementarity between capital and female workers. In a capital - abundant economy where female workers are more complementary with capital, trade induces an increase in the demand and the price of goods produced in sectors that demand relatively more female labor. The price increase leads to higher production and hence an inflow of male workers to these sectors. As a result, there will be dilution in the capital intensity, which results in a decline in the productivity hence the wages of female workers. ${ }^{19}$ The next section presents the empirical evidence for all the different theories discussed.

\section{Literature Review}

Our paper sheds additional light on the controversial link between trade openness and the wage discrimination practiced against women in Turkey's manufacturing sector. In that regard, we provide

15 Almasifard, M. (2018). Gender Wage Gap in Selected Developing Upper-Middle Income Countries, International Journal of Development Issues, 17(2): 144.

16 Oostendorp, R. H. (2004). Globalization and The Gender Wage Gap, World Bank Policy Research Working Paper, 3256: 2-3.

17 Becker, G.S. (1971). The Economics of Discrimination, Chicago, The University of Chicago Press: 39-45.

18 Yahmed, 2017, 2-5.

19 Sauré, P., Zoabi, H. (2014). International Trade, the Gender Wage Gap and Female Labor Force Participation, Journal of Development Economics, 111: 17-33. 
a prominent contribution to the literature that examines whether or not increased trade exposure improves or worsens the relative earnings of women in the labor market. We also contribute to the literature that study the factors affecting the gender wage gap. Our particular focus on Turkey makes our paper part of the literature that examine the wage differential between men and women in Turkey.

Extensive research has been conducted to investigate the factors underlying the gender wage gap in many countries. Empirical evidence shows for developed countries like the US and Spain that segregation of women into jobs with low pay, account for a sizable fraction of the relative earnings of women. ${ }^{20},{ }^{21}$ Institutional factors have also been analyzed as a potential candidate for generating the gender wage gap. In particular how parental leave, child-care policies and pay-bargaining institutions affect the gender wage gap is studied in numerous works. This line of research examines the "glass ceiling", defined as a widening wage difference between men and women at the top of the wage distribution. The results of this research suggest that in countries with more generous workfamily policies, the wage gap at the bottom of the distribution is lower whereas the gap at the top is higher. Collective bargaining is discussed as another institutional factor affecting the women's wages indirectly through creating a more compressed wage distribution. Differing promotion and appointment procedures in labor markets where the appointment of a worker may depend on his/ her negotiation skills, and bargaining power affects the relative earnings of women in the labor market. ${ }^{22},{ }^{23}$ High wages at the bottom of the wage distribution may also make it difficult for highcareer women to afford the household and child-care help they need. Thus, women may have to opt for easier jobs, which may result in women performing better at the bottom and the middle of the wage distribution and worse at the top. ${ }^{24}$

In addition to all these factors, there is an extensive literature that study how the trade exposure of countries affect the relative wage earnings of female workers. Similar to the theoretical arguments about the link between trade openness and wage discrimination, the empirical findings in the literature provide mixed results. Numerous studies on advanced and emerging markets support the neoclassical theory and Becker's theory of discrimination. ${ }^{25},{ }^{26}$ The degree of competitiveness is also found as an important determinant of the trade-gender wage gap link. Evidence from U.S. reveals that trade exposure narrows down the gender wage gap in concentrated industries whereas it has an opposite effect in unconcentrated industries. ${ }^{27}$

20 Bayard et al., 2003, 887-922.

21 Amuedo-Dorantes, de la Rica, 2005.

22 Arulampalam et al., 2007, 163-186.

23 Antonczyk et al., 2010, 835-847.

24 Albrecht et al., 2003, 145-177.

25 Artecona, R., Cunningham, W. (2002). Effects of Trade Liberalization on the Gender Wage Gap in Mexico, The World Bank Development Research Group/ Poverty Reduction and Economic Management Network, No. 34144.

26 Greaney, T., Tanaka, A. (2020). Foreign Ownership, Exporting and Gender Wage Gaps: Evidence from Japanese Linked Employer-Employee Data, Munich Personal Repec Archive, Mpra Paper No. 101339.

27 Black, S. E., Brainerd, E. (2004). Importing Equality: The Impact of Globalization on Gender Discrimination, Sage Publications, Inc., 57(4): 540-559. 
Trade openness may have impacts on the technology choice of firms, which in turn, may affect the gender wage gap. If exporting firms adopt a new technology, which favors blue-collar female workers, trade will diminish the pay gap between men and women. This theory is verified by empirical evidence from Mexico where firms became exporters after NAFTA, updated their machinery and equipment. The labor market outcomes of females in these new exporter firms improved which implies that trade openness works in favor of women in the labor market. ${ }^{28}$ Trade may have differential effects on female workers depending on the skill content of the job. Women working in low skill occupations is found as benefiting from trade in both rich and poor countries. In rich countries, trade narrows down gender wage gap in high-skill occupations as well. ${ }^{29}$.

Meanwhile, a significant number of papers show empirical evidence that trade has either no or worsening effect on the gender wage gap for both developed and developing countries. ${ }^{30},{ }^{31},{ }^{32}$.In markets with a high degree of concentration, competition from foreign trade results in higher wage discrimination between men and women. ${ }^{33},{ }^{34}$

Besides the market structure channel, another view suggests that exporting firms exhibit a greater gender wage gap than non-exporters because the increased competition exporters face necessitate more committed and flexible workers. Women are usually perceived as having less of these two characteristics compared to men thus generating a higher gender wage gap in exporting firms. ${ }^{35,36}$ The literature also discusses that the impact of trade on male-female wage differentials may vary among different demographic groups. It is shown that higher trade openness generates a lower gender wage gap among unskilled workers but it leads to a higher gender wage gap among high-skill workers. ${ }^{37}, 38$

The impact of the degree of trade exposure on women's relative earnings is also studied in the literature. Results of these studies show that gender wage gap is higher, the higher is the share of output exported, the number of markets served, and the number of export varieties. Similar to exports, the import intensity of an industry is also predicted to worsen the wage gap between men and women. ${ }^{39}$

28 Juhn et al., 2014, 179-193.

29 Oostendorp, 2004, 18-21.

30 Sauré, Zoabi, 2014, 17-33.

31 Musazay, S. (2019). Gender Wage Gap and International Trade: Evidence from Turkey’s Manufacturing Sector, Ibn Haldun University, Unpublished Master's Thesis.

32 Wei, H., Yang, S., Liu, S., Wu, J., Xiang, S. (2013). International Trade and Gender Wage Gap in China, European Scientific Journal, 9(22): 21-52.

33 Pérez, R.E.R., Lugo, D.C. (2017). Trade Liberalization and Gender Wage Gap in Mexico, Modern Economy, 8: $1167-1185$.

34 Menon, N., Rodgers, Y. (2009). International Trade and The Gender Wage Gap: New Evidence from India’s Manufacturing Sector, World Development, 37(5): 965-981.

35 Boler, E. A., Javorcik, B., Ulltveit-Moe, K. H. (2015). Globalization: A Woman's Best Friend? Exporters and The Gender Wage Gap, Center For Economic Studies and Info Institute, Working Paper No. 5296.

36 Boler, E. A., Javorcik, B., Ulltveit-Moe, K. H. (2018). Working Across Time Zones: Exporters And The Gender Wage Gap, Journal of International Economics, 111: 122-133.

37 Yahmed, 2012, 1-33.

38 Juhn et al., 2014, 179-193.

39 Deb, K., Hauk, W. R. (2020). The Impact of Chinese Imports on Indian Wage Inequality, The Indian Journal of Labour Economics, 63: 267-290. 
The link between trade openness and the gender wage discrimination is analyzed previously for Turkey using 2006 Household Labor Force Survey data and trade statistics. The results of this paper reveal that there is a larger gender wage gap in tradable sectors in than non-tradable sectors. ${ }^{40}$ Our paper differs from this existing work in various dimensions. First of all, in our analysis, we use 2010 and 2014 Structure of Earnings Survey data. This data provides additional information on firm characteristics such as firm size and union coverage which we include as controls in our wage regressions. Besides this, we concentrate on the manufacturing sector rather than all sectors in the economy. Moreover, instead of measuring the impact of trade on the gender wage gap along the binary scale of tradable vs. non-tradable, we quantify this effect along the intensive margin by using the export intensity of a sector as a proxy for trade openness. We also analyze the relationship between trade openness and the gender wage gap for different skill groups which is absent in existing studies done for Turkey.

Our paper is also part of the literature that examines the gender wage gap in Turkey. Previous studies use various data sources to tackle this question, which include the Household Income and Expenditure Survey and Wage Structure Survey of various years. They estimate an overall gender wage gap that range between 4 to $35 \%{ }^{41},{ }^{42},{ }^{43}$ The wage inequality between men and women in Turkey has also been examined for different categories of workers, such as the wage workers and self-employed, public and private, those working in covered and uncovered sectors. ${ }^{44},{ }^{45},{ }^{46}$. These studies all reach the same conclusion that there is significant discrimination against women in all segments of the economy. More recent studies use the Structure of Earnings Survey and Household Labor Force Surveys. The range of overall gender wage gap estimates vary between 3 and $13 \% .{ }^{47,48}$

Estimates of the gender wage gap for different education categories using 2004 and 2011 Labor Force Surveys in Turkey settle on a wide range. Low-educated women earn $24 \%$ less than their male counterparts whereas the male-female wage differential falls to $9 \%$ for tertiary-educated group in 2011. Looking at public and private sectors separately, unexplained part of the gender wage gap is predicted to be larger for women with high education in public sector. These differences reveal

40 Aydıner-Avsar, N. (2010). International Trade and Gender Wage Gap: A Distributional Analysis for Turkey, University of Utah, Working Paper: 1-33.

41 Dayığlu, M., Kasnakoğlu, Z. (1997). Kentsel Kesimde Kadın ve Erkeklerin İşgücüne Katılımları ve Kazanç Farklılıkları, Metu Studies In Development, 24(3): 329-361.

42 Ilkkaracan, İ., Selim, R. (2007). The Gender Wage Gap in The Turkish Labor Market, Review of Labour Economics And Industrial Relations, 21(2): 563-59.

43 Kara, O. (2006 ). Occupational Gender Wage Discrimination in Turkey, Journal of Economic Studies, 33(2): 130-143.

44 Tansel, A. (2001). Wage Earners, Self-Employed And Gender in The Informal Sector in Turkey, Economic Research Forum Working Paper, No. 0102.

45 Özcan, K. M., Özcan, Y. Z., Üçdoğruk, S. (2003). Wage Differences By Gender, Wage and Self Employment in Urban Turkey, Journal of Economic Cooperation, 24(1): 1-24.

46 Tansel, A. (2004). Public-Private Employment Choice, Wage Differentials and Gender in Turkey, Iza Discussion Papers, 53(2): 1-43.

47 Aktas, A., Uysal, G. (2016). The Gender Wage Gap in Turkey, Marmara Üniversitesi İktisadi ve İdari Bilimler Dergisi, 38(2): 1-19.

48 Tekgüç, H., Eryar, D., Cindoğlu, D. (2017) Women's Tertiary Education Masks the Gender Wage Gap in Turkey, Journal of Labor Research, 38: 360-386. 
the importance of their disaggregated analysis and show that analyses done with aggregated data might conceal important heterogeneous outcomes. ${ }^{49}$ We contribute to this literature by analyzing the gender wage gap in Turkey using more recent data. Moreover, our analysis extends the previous literature by examining the link between trade exposure on female wages and how this link varies for different skill categories.

\section{Data and Methodology}

\subsection{Data}

The first data source is the 2010 and 2014 waves of the Structure of Earnings Survey (SES) conducted with wage and salary workers in Turkey by the Turkish Statistical Institute (TURKSTAT). ${ }^{*}$ This survey provides individual-level data on worker characteristics, such as age, gender, education level. Besides these, work-related data of individuals which include tenure in the current job, occupation, administrative duty status, their union coverage, part-time/full-time position, type of the job, hours worked in the reference week, days worked in reference month, gross monthly salary payments, annual gross wage and salary payments and number of paid days in a year. The dataset provides information on important firm characteristics such as firm size, the 2-digit code of the sector in Nace Rev. 2 classification as well.

By combining individual-level and firm-level information, the dataset provides a valuable opportunity to examine how sector and firm-related variables affect the labor market outcomes of a different group of workers. The sample we select from SES consists of full-time workers employed in the manufacturing sector, aged between 15 and 65 who earn at least the minimum wage. Minimum wage in 2010, 2014 are taken as $761 \mathrm{TL}$ and $1071 \mathrm{TL}$, respectively. This leaves us with 80,095 observations in our sample of which around $80 \%$ are men and $20 \%$ are women.

In this paper, we study the link between the export intensity and gender wage gap to understand whether or not increased trade openness affects the wage inequality between men and women. We combine the individual, sector, and firm-level data provided in SES with sector-level exports and industrial production data provided by TURKSTAT. Sectoral export data are retrieved from Foreign Trade Statistics Database and sector-level production data are extracted from Annual Industry and Services Survey. ${ }^{50}$ We construct the export intensity of each subsector by dividing the total value of their annual exports by their production value. Based on these export intensities, we divide the sectors to 4 quartiles, i.e. $0-25 \%, 25-50 \%, 50-75 \%, 75-100 \%$.

49 Tekgüç et al,. 2017, 360-386.

* Currently, three waves of the survey for the years 2006, 2010, 2014 are available. We use 2010 and 2014 waves since the 2006 survey provides sector information using Nace Rev. 1 classification. For 2010 and 2014, sector information is available at two digits in Nace Rev. 2 classification. Harmonization of the sector information provided in these 3 years results in aggregation of the sector-level data. To avoid the loss of cross-sector variation, we use 2010 and 2014 waves of the SES.

50 Trade data is retrieved from https://data.tuik.gov.tr/Kategori/GetKategori?p=Foreign-Trade-104, and Industry production data is retrieved from https://data.tuik.gov.tr/Kategori/GetKategori?p=Industry-114 (Accessed on: $5.11 .2020)$ 
Table 1 provides some descriptive statistics of the sample. The average monthly wage earnings in the sample are 1,696 TL. Females earn on average 1,580 TL whereas male workers in the sample earn $1,726 \mathrm{TL}$. The average age of the workers is 34 with women being slightly younger than men are. The distribution of the sample into five education categories shows that around $80 \%$ of the sample has below college education. The share of college-educated among female workers is $30 \%$. This is significantly higher than the same share among males, which is $17.5 \%$. Hence, in our sample women have, on average a higher level of education.

The distribution of workers according to sector quartiles by export intensity looks almost uniform for the whole sample. The share of female workers in the top quartile is the highest with $31 \%$ whereas only $20 \%$ of the male workers work in the sectors with the highest export intensity. Lastly looking at the size distribution of firms, we see that more than one-third of the workers in the sample work in the smallest firms with 10-49 workers. Firms with more than 1000 employees account for only $8 \%$ of the whole sample. The share of both female and male workers declines as firm size increases.

Table 1: Sample Descriptive Statistics (2010 and 2014)

\begin{tabular}{|c|c|c|c|c|c|c|c|}
\hline & Male & Female & Total & & Male & Female & Total \\
\hline Monthly wage & 1726 & 1580 & 1696 & Machine operators & 26.4 & 19.6 & 25.2 \\
\hline Age & 34.8 & 33.4 & 34.1 & Elemen.Occ. & 11.2 & 15.6 & 11.9 \\
\hline Education (\%) & & & & Sector quartiles & & & \\
\hline Primary School & 27.8 & 24.1 & 27.1 & $0-25 \%$ & 27.8 & 26.1 & 27.5 \\
\hline Secondary School & 20.4 & 15.8 & 19.6 & $25-50 \%$ & 25.9 & 21.6 & 25.2 \\
\hline High School & 19.2 & 22.4 & 19.8 & $50-75 \%$ & 26.0 & 21.1 & 25.1 \\
\hline Voc. High School & 14.9 & 7.5 & 13.6 & $75-100 \%$ & 20.2 & 31.1 & 22.2 \\
\hline College and above & 17.5 & 29.9 & 19.7 & No union coverage (\%) & 83.6 & 91.6 & 85.1 \\
\hline Occupation (\%) & & & & No adm. duty (\%) & 15.3 & 13.7 & 15.1 \\
\hline Managers & 4.9 & 5.1 & 4.9 & & & & \\
\hline Professionals & 5.1 & 9.6 & 5.8 & Size (\%) & & & \\
\hline Technicians & 9.1 & 9.8 & 9.2 & $10-49$ & 34.7 & 36.9 & 35.1 \\
\hline Clerks & 6.4 & 18.3 & 8.6 & 50-249 & 22.4 & 22.1 & 22.4 \\
\hline Service workers & 3.9 & 5.4 & 4.2 & \begin{tabular}{|l|}
$250-499$ \\
\end{tabular} & 19.3 & 19.4 & 19.4 \\
\hline Skilled people & 0.14 & 0.06 & 0.12 & \begin{tabular}{|l|}
$500-999$ \\
\end{tabular} & 15.5 & 13.9 & 15.2 \\
\hline Craft, trade & 32.7 & 16.3 & 29.8 & $1000+$ & 8.0 & 7.5 & 7.9 \\
\hline
\end{tabular}

Source: Survey of Earnings Data (2010 and 2014), TURKSTAT, and Authors' Calculations.

\subsection{Methodology}

This study aims to estimate the degree to which trade openness affects the wage inequality between male and female workers. To accomplish this goal, we incorporate the sector-level export intensity (Int.ex) as an indicator of the trade exposure of each sector and its interaction with a gender dummy (Int.ex* I_male) to a standard wage regression along with a set of controls. The export intensity is computed by dividing the total exports value of each sector by its total production value. The individual-level control variables included in our baseline wage regression are the age of an individual, 
his/her tenure at the current firm, gender dummy (female is the baseline category), dummy variables for education level (primary school is the baseline category), dummy variables for each occupation category (managers are the baseline category), a dummy variable indicating whether or not the individual has an administrative duty. Firm and sector level controls included can be listed as dummy variables for different firm size (firms with less than 50 employees is the baseline), whether or not the firm is under a collective wage agreement (I_union), the export intensity of each sector (Int.ex), the logged value of sectoral production $\left(\mathrm{Q}_{\mathrm{kt}}\right)$. We also control for year fixed effects denoted by $\gamma_{t}$. The baseline wage regression is presented in Equation (1) below.

$$
\operatorname{lnW}_{i j k t}=\alpha+\beta_{1} X_{i}+\beta_{2} \text { Size }_{j}+\beta_{3} I_{-} \text {union }_{j}+\beta_{4} \text { Int. ex }_{k t}+\beta_{5}\left(\text { Int. ex }_{k t} x I_{\text {male }_{i}}\right)+\beta_{6} \ln Q_{k, t}+\gamma_{t}+\varepsilon_{i j k t}
$$

Here $\mathrm{i}, \mathrm{j}, \mathrm{k}$ represents individual, firm and sector, respectively and $\mathrm{t}$ denotes the year. Our dependent variable is the logged value of hourly wages $\left(\ln W_{i j k t}\right)$. We compute the hourly wages using data on the weekly hours worked and monthly wages available in the SES data. As a further exploration of the link between export intensity and the gender wage gap, we divide sectors into four quartiles according to their export intensities. Then we estimate the following equation separately for the four quartiles.

$$
\ln W_{i j k t}=\alpha+\beta_{1} X_{i}+\beta_{2} \text { Size }_{j}+\beta_{3} I_{-} \text {union }_{j}+\beta_{4} I_{-} \text {male }_{i}+\beta_{5} \ln Q_{k, t}+\gamma_{t}+\varepsilon_{i j k t}
$$

Similar to Equation (1), our individual-level control variables are included in ${ }^{X_{i}}$. This time we focus on the coefficient of the gender dummy $\left(I_{-}\right.$male $\left._{i}\right)$ for which the baseline category is the female workers. A comparison of this coefficient $\left(\beta_{4}\right)$ across all sector quartiles shows how the wage earnings of two gender groups differ from each other.

Lastly, we are interested in learning whether or not a sector's degree of trade exposure has a differential impact on the gender wage gap across different education categories. We study this question by estimating the following equation for the four sector quartiles, separately.

$$
\ln _{i j k t}=\alpha+\beta_{1} X_{i}+\beta_{2} \text { Size }_{j}+\beta_{3} I_{-} \text {union }_{j}+\beta_{4}\left(I_{-} \text {male }_{i} x I_{-} s k i l l_{i}\right)+\beta_{5} \ln Q_{k, t}+\gamma_{t}+\varepsilon_{i j k t}
$$

The coefficient of the interaction between gender dummy and skill dummy provides the answer to this question. We construct the skill categories based on the education categories information provided in the survey. We group workers with college and above education as skilled and other education groups as unskilled. The baseline category against which we compare our coefficients of all the interaction categories is the unskilled females (i.e. $I_{-}$male $=0$ I_skill $=0$ ). In all of the estimations, we cluster standard errors at the sector level. This controls for a possible correlation in the residuals for individuals within each sector category. Our estimation results and their discussion are provided in the next section.

\section{Results}

The estimation results for the baseline wage regression in Equation (1) are reported in Table 2. The coefficient estimates of the control variables included in the regression have expected signs. According to these results, age and tenure have positive and significant impacts on wage earnings. 
The coefficient estimates of the dummy variables for education levels show that as the education level of an individual improves, the wage earnings also increase. The coefficients of the occupation categories report how the wage earnings of these groups differ from the baseline category, which is managers. All the occupation categories have negative and significant coefficient estimates implying that they earn less compared to the baseline group.

The estimate of the no administrative duty coefficient, which is -0.18 , implies that workers having an administrative position earns almost $20 \%$ higher compared to other workers. Not being covered by a union seems to have no significant effect on average wages. On the other hand, firm size affects average wage earnings positively and significantly. The estimates for these coefficients imply the higher is the size of the firm, the higher is the average wage earnings of the workers are with respect to the baseline category of firms with less than 50 employees. Lastly, the coefficient of the logged value of industrial production has a negative and significant effect on wage earnings. An interpretation of this together with the firm-size coefficient estimates is that small firms that produce high values of output pay on average the smallest wages to their workers.

The main objective of this research is to analyze the link between the degree to which a firm is involved with trade, which is measured by export intensity, and the wage gap between male and female workers. Hence, the coefficient of interest belongs to the interaction term Male $x$ Export Intensity. This coefficient measures how much the wage of a male worker differs from that of a female worker with increasing export intensity. The regression results point to an estimate of 0.17 which is significant at a $10 \%$ level. This result implies that a 1-percentage point increase in the export intensity of the manufacturing firms produces a $0.17 \%$ higher male wages compared to female wages. Based on this estimate, we can infer that in a firm whose exports are on average $70 \%$ of its total production value pays the gender wage gap is $8.5 \%$ more than the firm with an export intensity of $20 \%$ is.

As a further investigation of the gender wage gap and its link with the export intensity of manufacturing sectors we divide these sectors into four quartiles according to their export intensity levels and run the regression specified in Equation (2) for each of them separately. The analysis yields similar coefficient estimates for individual and firm-specific control variables, i.e., age, tenure, education levels, occupation categories, administrative duty and union coverage dummies, firm size. A comparison of the coefficient estimate for the male dummy for each quartile provides evidence on how female workers are negatively discriminated against men in terms of their wage earnings.

Table 2: Baseline Estimation Results

\begin{tabular}{|l|l|l|l|}
\hline $\begin{array}{l}\text { Dependent Variable: Log Hourly Wages } \\
\text { Age }\end{array}$ & $0.008^{* * *}$ & Crafts, Trade & $-0.526^{* * *}$ \\
& $(0.001)$ & & $(0.039)$ \\
\hline Tenure & $0.019^{* * *}$ & Machine operators & $0.563^{* * *}$ \\
& $(0.001)$ & & $(0.040)$ \\
Male & 0.030 & Elemen. Occ & $-0.578^{* * *}$ \\
& $(0.037)$ & & $(0.040)$ \\
\hline
\end{tabular}




\begin{tabular}{|c|c|c|c|}
\hline Male x Export Int. & $\begin{array}{l}0.167^{\star} \\
(0.086) \\
\end{array}$ & No adm. duty & $\begin{array}{l}-0.180^{\star * *} \\
(0.012)\end{array}$ \\
\hline $\begin{array}{l}\text { Education Levels } \\
\text { Secondary School }\end{array}$ & $\begin{array}{l}0.067^{\star * \star} \\
(0.006)\end{array}$ & No union & $\begin{array}{l}-0.021 \\
(0.024)\end{array}$ \\
\hline High School & $\begin{array}{l}(0.006) \\
0.084^{* * *} \\
(0.007)\end{array}$ & $\begin{array}{l}\text { Size } \\
50-249\end{array}$ & $\begin{array}{l}0.125^{\star \star \star} \\
(0.014)\end{array}$ \\
\hline Vocational School & $\begin{array}{l}0.136^{\star * *} \\
(0.012)\end{array}$ & $250-499$ & $\begin{array}{l}0.179^{* * *} \\
(0.016)\end{array}$ \\
\hline College and above & $\begin{array}{l}0.386^{* * *} \\
(0.021) \\
\end{array}$ & $500-999$ & $\begin{array}{l}0.204^{\star * *} \\
(0.025)\end{array}$ \\
\hline $\begin{array}{l}\text { Occupation Types } \\
\text { Professionals }\end{array}$ & $\begin{array}{l}-0.139^{\star *} \\
(0.065)\end{array}$ & $\begin{array}{l}1000+ \\
\text { Log. Prod. Value }\end{array}$ & $\begin{array}{l}0.280^{* * *} \\
-0.049^{* *} \\
(0.021)\end{array}$ \\
\hline Technicians & $\begin{array}{l}-0.389^{* * *} \\
(0.034)\end{array}$ & Export intensity & $\begin{array}{l}-0.091 \\
(0.108)\end{array}$ \\
\hline Clerks & $\begin{array}{l}-0.476^{\star * *} \\
(0.036)\end{array}$ & Constant & $\begin{array}{l}8.472^{\star * *} \\
(0.540)\end{array}$ \\
\hline Service workers & $\begin{array}{l}-0.496^{\star * *} \\
(0.036)\end{array}$ & $\begin{array}{l}\text { Observations } \\
\text { R-squared }\end{array}$ & $\begin{array}{l}76,607 \\
0.544\end{array}$ \\
\hline Skilled people & $\begin{array}{l}-0.643^{\star * *} \\
(0.046)\end{array}$ & Year Fixed Effect & YES \\
\hline
\end{tabular}

Note: Standard errors are presented in parentheses. ${ }^{* * *},{ }^{* *},{ }^{*}$ indicate significance at $1 \%, 5 \%$ and $10 \%$ levels, respectively.

In the bottom quartile, the coefficient of the male dummy is 0.024 but insignificant. The second column provides the same results for the 25 th-50th percentile. This time the male dummy coefficient is 0.07 and significant at $1 \%$. This result shows that male workers earn on average $7 \%$ more than their female counterparts in sectors whose export intensity lies in the 25th-50th percentile. In column 3, the coefficient for the male dummy is provided for the sample of industries with export intensity in the 50-75th percentile. This coefficient is 0.089 implying that men working in these subsectors of manufacturing earn on average $9 \%$ more than women with the same observable characteristics. Lastly, column 4 shows the results of the regression where the sample includes industries whose export intensity lies in the top $25 \%$. The male dummy coefficient is estimated as 0.128 and it is significant at a $1 \%$ level. Males' wages in these export-intensive industries are on average $13 \%$ higher than female wages. A pattern of simultaneously increasing the gender wage gap and export intensity is sustained for all quartile levels and the negative discrimination of women in terms of their wages becomes more severe in sectors that export a higher fraction of their output.

Between the least export intensive and most export intensive industries, the gender wage gap rises significantly by around 10 percentage points (from $2.4 \%$ to $13 \%$ ). The difference between the average value of export intensity in the bottom and top quartile are $8.7 \%$ and $53.6 \%$. Hence, we can conclude that on average 45 -percentage points rise in the ratio of sectoral exports to output generates a 10 -percentage points higher wage inequality between men and women. 
Our finding provides support to the line of arguments in the literature, which defend the view that openness to trade harms the relative wage earnings of female workers with respect to their male counterparts. One of these studies measure the impact of trade on residual wage inequality between men and women using alternative measures of trade openness for India. The estimation results using exports to output ratio as a proxy for trade openness shows that a 1 percent rise in the export to output ratio generates a 0.48 percent higher residual wage inequality between men and women. A stronger effect is estimated for sectors that are more concentrated. ${ }^{51}$

Our estimate of the impact of export intensity on gender wage gap is smaller. This is an expected outcome since we analyze a different country and using different data sources. It can also be an outcome of the manufacturing sector in our sample being less concentrated than it is in the sample analyzed in their work. At this point, we contain our analysis to understanding the impact of trade on gender wage inequality and plan to explore the possible the underlying reasons of this relation in future work.

How does this inequality between male and female earnings change according to their skill levels? Previous work that address this question conclude that a rise in trade openness hurts skilled workers more than unskilled ones. ${ }^{52}, 53$

Table 3: Estimation Results of Log Hourly Wages for Export Intensity Quartiles

\begin{tabular}{|c|c|c|c|c|}
\hline & $0-25^{\text {th }}$ percentile & $25^{\text {th }}-50^{\text {th }}$ percentile & $50-75^{\text {th }}$ percentile & $\begin{array}{l}75-100^{\text {th }} \\
\text { percentile }\end{array}$ \\
\hline Age & $\begin{array}{l}0.008^{* * *} \\
(0.002)\end{array}$ & $\begin{array}{l}0.006^{* * *} \\
(0.001)\end{array}$ & $\begin{array}{l}0.008^{* * *} \\
(0.001)\end{array}$ & $\begin{array}{l}0.009^{* *} \\
(0.002)\end{array}$ \\
\hline Tenure & $\begin{array}{l}0.017^{\text {} * *} \\
(0.002)\end{array}$ & $\begin{array}{c}0.021^{* * *} \\
(0.003)\end{array}$ & $\begin{array}{c}0.020^{* * *} \\
(0.002)\end{array}$ & $\begin{array}{l}0.016^{* *} \\
(0.004)\end{array}$ \\
\hline Male dummy & $\begin{array}{l}0.024 \\
(0.037) \\
\end{array}$ & $\begin{array}{l}0.068^{\star * *} \\
(0.015)\end{array}$ & $\begin{array}{l}0.089^{\star * *} \\
(0.021)\end{array}$ & $\begin{array}{l}0.128^{\star * *} \\
(0.019)\end{array}$ \\
\hline Constant & $\begin{array}{l}8.490^{\star * *} \\
(0.517)\end{array}$ & $\begin{array}{l}7.750^{* * *} \\
(1.334)\end{array}$ & $\begin{array}{l}8.009^{* * *} \\
(1.446) \\
\end{array}$ & $\begin{array}{l}9.764^{* * *} \\
(0.681)\end{array}$ \\
\hline Observations & 21,088 & 19,273 & 19,253 & 16,993 \\
\hline R-squared & 0.566 & 0.475 & 0.532 & 0.612 \\
\hline Year Fixed Effect & YES & YES & YES & YES \\
\hline
\end{tabular}

Note: Standard errors, clustered at sector level, are presented in parentheses. ${ }^{* * *},{ }^{* *},{ }^{*}$ indicate significance at $1 \%, 5 \%$ and $10 \%$ levels, respectively.

Our answer to this question is provided in Table 4. Table 4 provides estimates of the regression described in Equation (3). The coefficients of the interaction term between a male dummy (I_m) and a dummy variable whether the individual is skilled or not (I_s) measure how the wage differential between men and women changes with the export intensity. Individuals with a college education

51 Menon, Rodgers, 2009, 974-975.

52 Juhn, et al., 2014, 179-193.

53 Yahmed, 2012, 1-33. 
and above are categorized as skilled, i.e. I_s=1. The remaining education categories build up the unskilled category implying I_s $=0$. The baseline of these groups formed with skill and male dummy interaction is unskilled females where I_s $=$ I_m $=0$. Hence all the coefficients of these interaction terms show how the wage of each category fare against the unskilled female workers.

The gender wage gap among unskilled individuals is measured by the coefficient estimate of the interaction term where I_m $=1$ and I_s $=0$. This coefficient reveals how much the wages of unskilled men differ from that of unskilled women. Similar to Table 3, the results are presented for different export intensity quartiles of sectors. Just like the results in this table, unskilled male workers earn significantly higher than unskilled women. The wage gap between these groups rises with export intensity ranging between $5 \%$ and $12 \%$. The gender wage gap among unskilled workers resemble the overall gender wage gap estimates displayed in Table 3.

The coefficients of the male and skill dummy interaction do not provide a direct estimate of the gender wage gap among the college graduates. To compute that, I subtract the coefficient estimate of the skilled-male category from the skilled-female and test for the significance of this difference. These results are reported in Table 5. Except for the bottom quartile, men earn on average significantly more than women in all export-intensity categories do. The gender wage differential among the skilled varies between 7 to $18 \%$. The highest value of this estimate belongs to the top quartile, where college and above-educated men earn on average $19 \%$ more than women of the same education level. This value is higher than the $12 \%$ gap estimated for the unskilled workers. Hence, it is clear that firms that export more intensely negatively discriminate skilled females more than unskilled ones against their male counterparts. With this finding, we confirm the previous findings in the literature that skilled women face more intense wage discrimination as trade openness rises.

Based on this result, we can provide a conjecture about the reason for the negative impact of trade openness on the gender wage gap in Turkey. If skilled women are more complementary to capital and profits in the export-intensive sector rise with trade, an inflow of male workers to these sectors dilute the capital stock. The dilution in the capital stock affects the marginal product of skilled females hence result in a higher gender wage gap. ${ }^{54}$

Table 4: Estimation Results for Export Intensity Quartiles -High Skill vs. Low Skill

\begin{tabular}{|c|c|c|c|c|}
\hline & $0-25^{\text {th }}$ percentile & $\begin{array}{l}25^{\text {th }}-50^{\text {th }} \\
\text { percentile }\end{array}$ & $50-75^{\text {th }}$ percentile & \begin{tabular}{|l|l}
$75-100^{\text {th }}$ \\
percentile
\end{tabular} \\
\hline Age & $\begin{array}{l}0.006^{* * *} \\
(0.001)\end{array}$ & $\begin{array}{l}0.004^{* * *} \\
(0.001)\end{array}$ & $\begin{array}{l}0.006^{* * *} \\
(0.001)\end{array}$ & $\begin{array}{l}0.008^{* *} \\
(0.002)\end{array}$ \\
\hline Tenure & $\begin{array}{l}0.018^{* * *} \\
(0.002)\end{array}$ & $\begin{array}{l}0.021^{* * *} \\
(0.003)\end{array}$ & $\begin{array}{l}.020^{* * *} \\
(0.002)\end{array}$ & $\begin{array}{l}0.017^{* \star} \\
(0.004)\end{array}$ \\
\hline \multicolumn{5}{|c|}{ Male and Skill Interaction } \\
\hline I_m $=0 * I \_s=1$ & $0.354^{* * *}$ & $0.317^{\star * *}$ & $0.244^{* * *}$ & $0.286^{* * *}$ \\
\hline
\end{tabular}

54 Sauré,Zoabi, 2014, 17-33. 


\begin{tabular}{|l|l|l|l|l|} 
& $(0.061)$ & $(0.046)$ & $(0.050)$ & $(0.037)$ \\
\hline $\mathbf{I} \_\mathbf{m}=\mathbf{1}^{\star} \mathbf{I} \_\mathbf{s}=\mathbf{0}$ & $0.051^{*}$ & $0.075^{\star * *}$ & $0.093^{* * *}$ & $0.122^{\star * *}$ \\
& $(0.023)$ & $(0.011)$ & $(0.013)$ & $(0.026)$ \\
\hline $\mathbf{I} \_\mathbf{m}=\mathbf{1}^{*} \mathbf{I} \mathbf{s}=\mathbf{1}$ & $0.332^{* * *}$ & $0.386^{* * *}$ & $0.340^{* * *}$ & $0.463^{* * *}$ \\
& $(0.025)$ & $(0.038)$ & $(0.018)$ & $(0.011)$ \\
\hline Constant & $8.649^{* * *}$ & $7.932^{* * *}$ & $8.449^{* * *}$ & $9.970^{* * *}$ \\
& $(0.519)$ & $(1.461)$ & $(1.483)$ & $(0.713)$ \\
\hline Observations & 21,088 & 19,273 & 19,253 & 16,993 \\
\hline R-squared & 0.563 & 0.462 & 0.527 & 0.608 \\
\hline Year Fixed Effect & YES & YES & YES & YES \\
\hline
\end{tabular}

Note: Clustered standard errors are presented in parentheses. ${ }^{* * *},{ }^{* *},{ }^{*}$ indicate significance at $1 \%, 5 \%$ and $10 \%$ levels, respectively.

Table 5: Significance Test for the Difference between Skilled Male and Female Wage Differential

\begin{tabular}{|c|c|c|c|c|}
\hline & $0-25^{\text {th }}$ percentile & $25^{\text {th }}-50^{\text {th }}$ percentile & $50-75^{\text {th }}$ percentile & $75-100^{\text {th }}$ percentile \\
\hline $\boldsymbol{\beta}_{\left\{\mathbf{I}_{\mathbf{m}}=\mathbf{1} * \mathbf{I}_{\mathbf{s}}=\mathbf{1}\right\}}-\boldsymbol{\beta}_{\left\{\mathbf{I}_{\mathbf{m}}=\mathbf{0} * \mathbf{I}_{\mathbf{s}}=\mathbf{1}\right\}}$ & -0.022 & $0.069^{\star *}$ & $0.096^{*}$ & $0.177^{\star * *}$ \\
\hline F-stat & 0.18 & 5.18 & 3.85 & 30.85 \\
\hline p-value & 0.68 & 0.05 & 0.10 & 0.005 \\
\hline
\end{tabular}

Note: ${ }^{* *},{ }^{* *},{ }^{*}$ indicate significance at $1 \%, 5 \%$ and $10 \%$ levels, respectively.

\section{Conclusion}

Gender wage gap has important social and economic implications, especially for developing countries in both the short-run and the long run. In order to design effective policies to remedy this important issue, it is essential to understand its dynamics and the factors that contribute to it.

This paper discusses how increased trade exposure affects the wage gap between male and female workers in Turkey. We use individual level data provided by Structure of Earnings Survey for years 2010 and 2014 together with sector level trade and production value data in our study. The measure of trade is the export intensity of a sector. Our regression results show that a rise in export intensity generates a worsening in the gender pay gap. Hence, trade hurts female workers that work in manufacturing sector in Turkey. We further investigate how the gender wage gap varies among different skill categories. This analysis provides evidence that high-skill female workers lose more due to increased exports.

The results of our analysis provide empirical support to the non-neoclassical theories, which argue that trade aggravates the gender inequality in labor markets. Among the reasons for this outcome, previous research list lack of competition and a high degree of concentration in some sectors ${ }^{55}$, views about female workers as not being committed and flexible enough to work in exporting firms ${ }^{56}$. Capital and female labor complementing each other in the production process of exporters and the

55 Menon, Rodgers, 2009, 974-975.

56 Boler et al., 2018, 122-133. 
dilution of capital with an increase in male worker abundance due to increased profits in these firms has also been proposed as a mechanism through which trade deteriorates the relative wages of female workers. ${ }^{57}$

For Turkey, the negative impact of trade on the gender wage gap may be resulting from all or a combination of these factors. The bigger gender wage gap observed in skilled-female category makes the theory based on complementarity of capital and female labor a more likely potential candidate. Though the reason why trade impairs the labor market outcomes of women is essential to understand, we leave that important issue for future research.

\section{References}

AKTAS, A., Uysal, G. (2016). The Gender Wage Gap in Turkey, Marmara Üniversitesi İktisadi ve İdari Bilimler Dergisi, 38(2): 1-19.

ALBRECHT, J., Björklund, A., Vroman, S. (2003). Is there a Glass Ceiling in Sweden?, Journal of Labor Economics, 21(1): 145-177.

ALMASIFARD, M. (2018). Gender Wage Gap in Selected Developing Upper-Middle Income Countries, International Journal of Development Issues, 17(2): 142-156.

AMUEDO-DORANTES, C., De La Rica, S. (2005). The Impact of Gender Segregation on Male-Female Wage Differentials: Evidence from Matched Employer-Employee Data for Spain, IZA Discussion Papers 1742.

ANTONCZYK, D., Fitzenberger, B., Sommerfeld, K. (2010). Rising Wage Inequality: The Decline of Collective Bargaining, and The Gender Wage Gap, Labour Economics, 17: 835-847.

ARTECONA, R., Cunningham, W. (2002). Effects of Trade Liberalization on The Gender Wage Gap in Mexico, The World Bank Development Research Group/ Poverty Reduction and Economic Management Network, No. 34144.

ARULAMPALAM, W., Booth, A., Bryan, M. (2007). Is There a Glass Ceiling over Europe? Exploring the Gender Pay Gap across the Wage Distribution, ILR Review, 60 (2): 163-186.

AYDINER-AVSAR, N. (2010) International Trade and Gender Wage Gap: A Distributional Analysis for Turkey. University of Utah, Working Paper.

BAYARD, K., Hellerstein, J., Neumark, D., Troske, K. (2003). New Evidence on Sex Segregation and Sex Differences in Wages from Matched Employee-Employer Data, Journal of Labor Economics, 21(4): 887922.

BECKER, G. S. (1971). The Economics of Discrimination, Chicago, The University of Chicago Press.

BERIK, G., Rodgers, Y., R., Zveglich, J. E. (2004). International Trade and Wage Discrimination: Evidence from East Asia, Review of Development Economics, 8(2): 237-254.

BLACK, S. E., Brainerd, E. (2004). Importing Equality: The Impact of Globalization on Gender Discrimination, Industrial \& Labor Relations Review, 57(4): 540-559.

BOLER, E. A., Javorcik, B., Ulltveit-Moe, K. H. (2015). Globalization: A Woman's Best Friend? Exporters and The Gender Wage Gap, Center for Economic Studies and Info Institute, Working Paper No. 5296.

BOLER, E. A., Javorcik, B., Ulltveit-Moe, K. H. (2018). Working Across Time Zones: Exporters and The Gender Wage Gap, Journal of International Economics, 111: 122-133.

CHINHUI, J., Dae Il, K. (1999). The Effects of Rising Female Labor Supply on Male Wages, Journal of Labor Economics, 17(1): 23-48.

57 Sauré, Zoabi, 2014, 17-33. 
DAYIOGLU, M., Kasnakoglu, Z. (1997). Kentsel Kesimde Kadın ve Erkeklerin İşgücüne Katılımları ve Kazanç Farklılıkları, Metu Studies in Development, 24(3): 329-361.

DEB, K., Hauk, W. R. (2020). The Impact of Chinese Imports on Indian Wage Inequality, The Indian Journal of Labour Economics, 63: 267-290.

DUFLO, E. (2003). Grandmothers and Granddaughters: Old Age Pension and Intra-Household Allocation in South Africa, World Bank Economic Review, 17(1): 1-25.

FIELDS, J., Wolff, E. N. (1995). Interindustry Wage Differentials and The Gender Wage Gap, Industrial and Labor Relations Review, 49(1): 105-120.

GALOR, O., Weil, D. N. (1996). The Gender Gap, Fertility, and Growth, The American Economic Review, 86(3): 374-387.

GANNON, B., Plasman, R., Rycx, F., Tojerow, I. (2007). Inter-Industry Wage Differentials and The Gender Wage Gap: Evidence from European Countries, The Economic and Social Review, 38(1): 135-155.

GREANEY, T., Tanaka, A. (2020). Foreign Ownership, Exporting and Gender Wage Gaps: Evidence from Japanese Linked Employer-Employee Data, Munich Personal Repec Archive, MPRA Paper No. 101339.

HEIWAI, T., Yifan, Z. (2017). Do Multinationals Transfer Culture? Evidence on Female Employment in China, Center for Economic Studies and Info Institute, Cesifo Working Paper No. 6295.

HOLLWEG, C. H., Ong Lopez, A. (2020). Exporting and Female Labor Market Outcomes in Georgia, World Bank Policy Research Working Paper No. 9432.

ILKKARACAN, İ., Selim, R. (2007) The Gender Wage Gap in the Turkish Labor Market, Review of Labour Economics and Industrial Relations, 21(2): 563-59.

ILO (2012). International Standard Classification of Occupations Structure, Group Definitions and Correspondence Tables.

ILO AND TURKSTAT (2020). Measuring the Gender Wage Gap: Turkey Case: 1-21.

JUHN, C., Ujhelyi, G., Villegas-Sanchez, C. (2014). Men, Women, and Machines: How Trade Impacts Gender Inequality, Journal of Development Economics, 106: 179-193.

KARA, O. (2006). Occupational Gender Wage Discrimination in Turkey, Journal of Economic Studies, 33(2): 130-143.

LUGO, D. C., Pérez, R. E. R. (2017). Trade Liberalization and Gender Wage Gap in Mexico, Modern Economy, 8: 1167-1185.

MENON, N., Rodgers, Y. M. (2009). International Trade and the Gender Wage Gap: New Evidence from India’s Manufacturing Sector, World Development, 37(5): 965-981.

MUSAZAY, S. (2019). Gender Wage Gap and İnternational Trade: Evidence from Turkey's Manufacturing Sector. (Unpublished master's thesis). Ibn Haldun University, School of Graduate Studies, İstanbul.

OOSTENDORP, R. H. (2004). Globalization and The Gender Wage Gap, World Bank Policy Research Working Paper 3256.

ÖZCAN, K. M., Özcan, Y. Z., Üçdoğruk, S. (2003). Wage Differences by Gender, Wage and Self Employment in Urban Turkey, Journal of Economic Cooperation, 24(1): 1-24.

ÖZTÜRK, S., Başar, D. (2018). Türkiye’de Kadınların İşgücü Piyasasına Yönelik Tercihleri: Kayıt Dışı Sektör Özelinde Bir Analiz, Journal of Social Security, 8(2): 41-58.

PÉREZ, R. E. R., Lugo, D.C. (2017) Trade Liberalization and Gender Wage Gap in Mexico, Modern Economy, 8: 1167-1185.

SAURÉ, P., Zoabi, H. (2014). International Trade, The Gender Wage Gap and Female Labor Force Participation, Journal of Development Economics, 111: 17-33. 
SEGUINO, S. (1997). Gender Wage Inequality and Export-Led Growth in South Korea, The Journal of Development Studies, 34(2): 102-132.

TANSEL, A. (2001). Wage Earners, Self-Employed and Gender in The Informal Sector in Turkey, Economic Research Forum Working Paper, No. 0102.

TANSEL, A. (2004). Public-Private Employment Choice, Wage Differentials and Gender in Turkey, IZA Discussion Papers, 53(2): 1-43.

TEKGÜÇ, H., Eryar, D., Cindoğlu, D. (2017). Women’s Tertiary Education Masks the Gender Wage Gap in Turkey, Journal of Labor Research, 38: 360-386.

THOMAS, D. (1990). Intra-Household Resource Allocation: An Inferential Approach, Journal of Human Resources, 25(4): 635-664.

WEI, H., Yang, S., Liu, S., Wu, J., Xiang, S. (2013). International Trade and Gender Wage Gap In China, European Scientific Journal, 9(22): 21-52.

WORLD ECONOMIC FORUM (2019). Global Gender Report 2020. https://www.weforum.org/reports/gendergap-2020-report-100-years-pay-equality (Accessed on: 05.02.2021)

YAHMED, S. B. (2012). Gender Wage Gaps Across Skills and Trade Openness, AMSE Working Papers, 1232: $1-33$.

YAHMED, S. B. (2017). Gender Wage Discrimination and Trade Openness, Prejudiced Employers in an Open Industry, ZEW Discussion Papers No. 17-047: 1-53. 